\section{Australian Journal of \\ Crop Science}

\title{
Genetic diversity of Moroccan bitter vetch Vicia ervilia (L.) Willd. landraces revealed by morphological and SSR markers
}

\author{
Salama El Fatehi ${ }^{1,2}$, Gilles Béna ${ }^{2,4}$, Abdelkarim Filali-Maltouf ${ }^{2,3}$, Mohammed Ater ${ }^{1,2^{*}}$ \\ ${ }^{1}$ Laboratoire Diversité et Conservation des Systèmes Biologiques (LDICOSYB), Université Abdelmalek Essaâdi, \\ P.B. 2121, Tétouan, Morocco \\ ${ }^{2}$ Laboratoire Mixte International (LMI), Université Mohamed V-Agdal \& IRD, Avenue Ibn Batouta BP 1014, \\ Rabat, Morocco \\ ${ }^{3}$ Laboratoire de Microbiologie et Biologie Moléculaire, Université Mohamed V-Agdal, Avenue Ibn Batouta BP \\ 1014, Rabat, Morocco \\ ${ }^{4}$ Laboratoire des Interactions Plantes Microorganismes Environnement, Institut de Recherche pour le \\ Développement (IRD), 34398 Montpellier Cedex 5, France
}

*Corresponding author: mohammed.ater@gmail.com

\begin{abstract}
Bitter vetch (Vicia ervilia (L.) Willd) is a minor crop in the traditional agroecosystems of north-western Morocco. Polymorphism of microsatellite and morphological markers were used to investigate 19 Moroccan landraces by morphological and molecular markers. Thirteen morphological characters of the seed and pod showed great variability and differentiation between ecotypes. Eight microsatellite loci were used to study the genetic structure and diversity of bitter vetch landraces. SSR markers were very polymorphic and evidenced strong heterozygosity $\left(\mathrm{H}_{\mathrm{T}}=0.662\right)$. Heterozygote deficiency in relation to the regime self-fertilizing species was observed. A high level of diversity was observed within populations (81.72\%) while and only $18.28 \%$ among population. The differentiation of ecotypes is relatively important and there is little isolation by distance. Because of the rarity of this culture it is important to support ex situ and in situ conservation initiatives of these genetic resources.
\end{abstract}

Keywords :Vicia ervilia, bitter vetch, landraces, polymorphism, microsatellites, genetic resources.

Introduction

Bitter vetch, Vicia ervilia (L.) Willd is an ancient domesticated legume crop (Zohary et al., 2012). Indeed, archaeobotanical data have shown its presence around 65000 to 48000 years BC in the Kebara Cave in Israel (Lev et al., 2005). In the Western Mediterranean area, this culture seems more recent and it has only documented since the beginning of the Neolithic (i.e. 10,200-8,800 BC, Peña-Chocarro and Zapata, 2010). Currently, it is a minor crop grown in Southern Europe, Western and Central Asia and Northern Africa (GRIN, 2008). World production is estimated around 800000 tons per year with an average yield of 1.600 ton/ha (FAO, 2015). The primary use of bitter vetch seeds is as animal feed (Enneking, 1995; Francis et al., 1999), although, it has been consumed by humans during dearth periods. In the Mediterranean area, where rainfed agriculture is now facing threats mostly due to climatic uncertainties (Trnka et al., 2011), V. ervilia appears as a promising crop species: its adaptive capacities, especially tolerance to aridity, make it suitable for cultivation in situations of poor rainfall(Foury, 1954; Maxted, 1995 ; Abd El-Moneim and Saxena, 1997). In Morocco, it is grown in the northern part of the country (Foury, 1954). Actually, this culture is heavily marginalized and reduced to a small area. The cultivated area was estimated in the 80s and 90s around 20000 ha (Bounejmate, 1997) decreasing nowadays to 10000 ha (FAO, 2015). The varieties sown are landraces maintained by traditional farming practices within the traditional agro-ecosystem of the Rif Mountains (Hmimsa and Ater, 2008; Ater and Hmimsa, 2008). This local selection has resulted in the formation of ecotypes that may be adapted to local agro-climatic conditions. The diversity of these genetic resources is however almost unknown. At a phenotypic level, previous studies have shown that ecotypes were variable within populations and differentiated among populations, suggesting an underlying genetic diversity (El Fatehi et al., 2014). The study was carried out on landraces harvested directly from the field (in-situ). Local varieties generally present a more diversified genetic base than improved (modern) varieties, which are genetically more homogeneous (Frankel et al., 1995). Landraces are a source of genetic diversity for plant breeding. Under the hypothesis that these local varieties have differentiated in response to local conditions (edaphic, climatic and ecological) we will thus name these entities ecotypes rather than varieties or populations. Major advantages of ecotypes are adaptation to their specific agrosystems and low input requirements in traditional agriculture practices. Traditional agroecosystems are refuges for agrodiversity and local races in different cultures (Hmimsa and Ater, 2008; Djé et al., 2000, 2007; Lazaro et al., 2013). Hence, within a context of climatic transition and increasing food demand, there is a strong interest in local ecotypes genetic resources characterization and conservation. 
The assessment of the diversity and genetic structure of these ecotypes are essential for the conservation and valorization of genetic resources of this crop. Our study aims to contribute to this evaluation by using morphological and Simple Sequence Repeat (SSR) markers. A preliminary study (El Fatehi et al., 2013) allowed to adapt the DNA extraction protocol and to select SSR markers for this species. Despite their plastic response to environmental variation, morphological traits also have strong genetic bases that provide complementary information to that of neutral molecular markers, especially in terms of morphological and life cycle adaptation to local environmental parameters. In the present study, we examined 19 local bitter vetch ecotypes from Northern Western Morocco with 8 SSR markers and 13 morphological traits. Our objectives were to estimate the genetic diversity within and among ecotypes and compare morphological and genetic diversities.

\section{Results}

\section{Morphological markers:}

We characterized the size and the shape of seeds and pods, by measuring length, height, width, diameter and weight of the seeds, while the shape was characterized from the relationship among these measures (Table 1). The results of the analysis of variance for the various parameters show highly significant differences between the different populations ( $\mathrm{P} \leq 0.001$, Table 2$)$.

For seed parameters, the variance ratios $(\mathrm{F})$ that expressed differences among populations were higher for traits related to size than for shape. Seed height $(\mathrm{SH})$ and seed diameter (SD) present a highly significant $\mathrm{F}$ and a limited coefficient of variation (CV) (Table 2). SH ranged from small $(3.80 \mathrm{~mm})$ in the ecotype of Bouatou to large seeds $(4.54 \mathrm{~mm})$ in Dharlahdida. SD ranged from $3.59 \mathrm{~mm}$ (Bab el hourate) to $4.18 \mathrm{~mm}$ (Dharlahdida). The ratio of the two parameters (SH/SD) varied between 1.06 (representing a more spherical shape) and 1.1 (for more conical shape). However, the seed yield $(\mathrm{SY})$ is the least discriminating character $(\mathrm{F}=4.80)$ with the highest $\mathrm{CV}$. Indeed, it ranged between $0.03 \mathrm{mg}$ (Achakrad) and $0.05 \mathrm{mg}$ (Kramat) with an average of 0.04 $\mathrm{mg}$, and a coefficient of variation of $39.47 \%$. The weight of 100 seeds (HSW) varies from $3.30 \mathrm{~g}$ in Bab el hourrate to $5.09 \mathrm{~g}$ in Dharlahdida, with an average value of $3.93 \mathrm{~g}$, a value similar to the value of $3.72 \mathrm{~g}$ observed by Berger et al. (2002). Regarding the pod, the total length (PLT) mean is $21.86 \mathrm{~mm}$. It ranged between $19.88 \mathrm{~mm}$ in Tafifoute and $25.29 \mathrm{~mm}$ in Kramat, whereas the smallest value $(17.16 \mathrm{~mm})$ of the basal length (PLB) was observed in the population in Bouatou and the largest $(21.37 \mathrm{~mm})$ in Adrou. The mean values of the ratio (PLT/PLB) and the difference (PLT PLB) are respectively 1.13 and 2.46 corresponding to more or less slivered shape. The average weight of pods (PY) is 0.16 $\mathrm{mg}$, with the smallest sampled in Bab el hourrate $(0.12 \mathrm{mg})$ and the biggest in Dharlahdida $(0.21 \mathrm{mg})$. The number of seeds per pod (NSP) showed very little variation, with an average of 3.42 and a coefficient of variation $3.26 \%$. A hierarchical classification of 19 ecotypes was carried out using the mean values of all quantitative variables (Fig 1). It represented the similitudes among the different ecotypes based on Euclidean distance. Four groups are distinguished according to a size gradient. Group 1 is formed mostly by populations with large size, heavy seeds and pods. A group 2 and 3 includes intermediate forms while group 4 includes ecotypes with smaller seeds and pods. Some morphologically highly differentiated populations ascribed to group 1
(Kramat, Dharlahdida) and group 4 (Tatifoute, Bouatou) are located in the same area and belong to the same watershed. There is a limited relationship between the size gradient observed and geography, with only a slight tendency for the size of the pods and seeds to decrease from north to south. SSR markers:

\section{Genetic diversity among ecotypes}

The genotypes of 19 ecotypes of Vicia ervilia were characterized for 8 microsatellite loci (Supplementary Table 1). The level of polymorphism revealed by these markers is relatively high, with an average index of polymorphism (PIC) of $0.66 \pm 0.19$, an allelic richness $\left(\mathrm{A}_{\mathrm{p}}\right)$ of $8.12 \pm 4.88$ alleles and an average number of alleles per locus $\left(\mathrm{N}_{\mathrm{A}}\right)$ of $2.04 \pm 0.53$ (Table 3). The estimated effective number of alleles $\left(\mathrm{N}_{\mathrm{e}}\right)$ reaches $2.046 \pm 0.532$. The levels of polymorphism observed show however some heterogeneity, as it varies among loci, ranging from a minimum for VE27 to a maximum for VE07. Indeed, the major allele frequency $\left(\mathrm{M}_{\mathrm{AF}}\right)$ per locus ranges between 0.25 and 0.86 with an average at $0.45 \pm 0.19$. Other indices confirmed the high level of polymorphism and revealed heterogeneity among loci. Thus, the number of genotypes $\left(\mathrm{N}_{\mathrm{G}}\right)$ per locus varies from 4 to 21 , with an average at $10 \pm 5.75$. Nevertheless, observed heterozygosity values $\left(\mathrm{H}_{\mathrm{O}}\right)$ are low and vary between 0.012 and 0.044 with an average of $0.026 \pm 0.012$, whereas the values of expected heterozygosity $\left(\mathrm{H}_{\mathrm{E}}\right)$ are much higher and vary between 0.148 and 0.654 with an average is $0.477 \pm 0.156$. Thus, there is a deficit of heterozygous compared to Hardy-Weinberg expected values. Regarding the within-ecotype genetic diversity, the polymorphism of loci $(\mathrm{P})$ is very high and varies between 0.875 and 1 with an average of 0.861 , except for the population of Khizana that was monomorphic (Table $4)$. The average number of alleles per locus (NA) and ecotype is 3.02 and varies between 1 in monomorphic of Khizana ecotype and 3.87 in the ecotype "Pont Talambote". The observed heterozygosity $\left(\mathrm{H}_{\mathrm{O}}\right)$ is low and less than the expected heterozygosity $\left(\mathrm{H}_{\mathrm{E}}\right) ; 5$ ecotypes (Kramat, Khizana, Bab el Hourrate, Asserdoune and El Jabriyine) are homozygous.

\section{Genetic structure of studied accessions}

The Nei diversity indices were estimated for all ecotypes studied (Table 5). The total genetic diversity $\left(\mathrm{H}_{\mathrm{T}}\right)$, the genetic diversity within population $\left(\mathrm{H}_{\mathrm{S}}\right)$, the genetic diversity among population $\left(\mathrm{D}_{\mathrm{ST}}\right)$ and the coefficient of genetic differentiation $\left(\mathrm{G}_{\mathrm{ST}}\right)$ were calculated from the allele frequencies obtained at the various loci. The results show a relatively high level of genetic diversity with an average of $\mathrm{H}_{\mathrm{T}}=0.662$ and values that vary between 0.239 for VE27 and 0.871 for VE07. The bulk of this diversity is expressed at a within population level with $\mathrm{H}_{\mathrm{S}}=0.541$ that correspond to $81.72 \%$ of revealed diversity. In contrast, the differentiation among populations $\left(\mathrm{D}_{\mathrm{ST}}=0.121\right)$ is much smaller and included only $18.28 \%$ of the expressed diversity. Characterization of population structure was also evaluated according to the Wright's indices of fixation (Wright, 1969) (Table 6). The overall deficit in heterozygosity was confirmed with the values of the coefficient of inbreeding for the entire population $\left(\mathrm{F}_{\mathrm{IT}}=0.957\right)$ and the coefficient of inbreeding within each subpopulations $\left(\mathrm{F}_{\mathrm{IS}}=0.944\right)$. The values confirm a heterozygosity deficiency in relation to the self-fertilizing system. The genetic differentiation between populations $\mathrm{F}_{\mathrm{ST}}$ is 0.194 . The genetic distances of Nei calculated from mean values of the allele frequencies were used to produce a hierarchical classification 
Table 1. List of the morphological characters studied.

\begin{tabular}{ll}
\hline Character & Code \\
\hline Seed height $(\mathrm{mm})$ & SH \\
Seed diameter $(\mathrm{mm})$ & SD \\
Seed yield $(\mathrm{g})$ & $\mathrm{SY}$ \\
Hundred seed weight $(\mathrm{g})$ & $\mathrm{HSW}$ \\
Seed height / Seed diameter & SH/SD \\
Pod length total $(\mathrm{mm})$ & PLT \\
Pod length basal $(\mathrm{mm})$ & PLB \\
Pod width $(\mathrm{mm})$ & PW \\
Number of the seed per pod & NSP \\
Pod yield $(\mathrm{g})$ & PY \\
Pod length total / Pod length basal & PLT / PLB \\
Pod length total - Pod length basal & PLT - PLB \\
Pod length total / Pod width & PLT/ PW \\
\hline
\end{tabular}

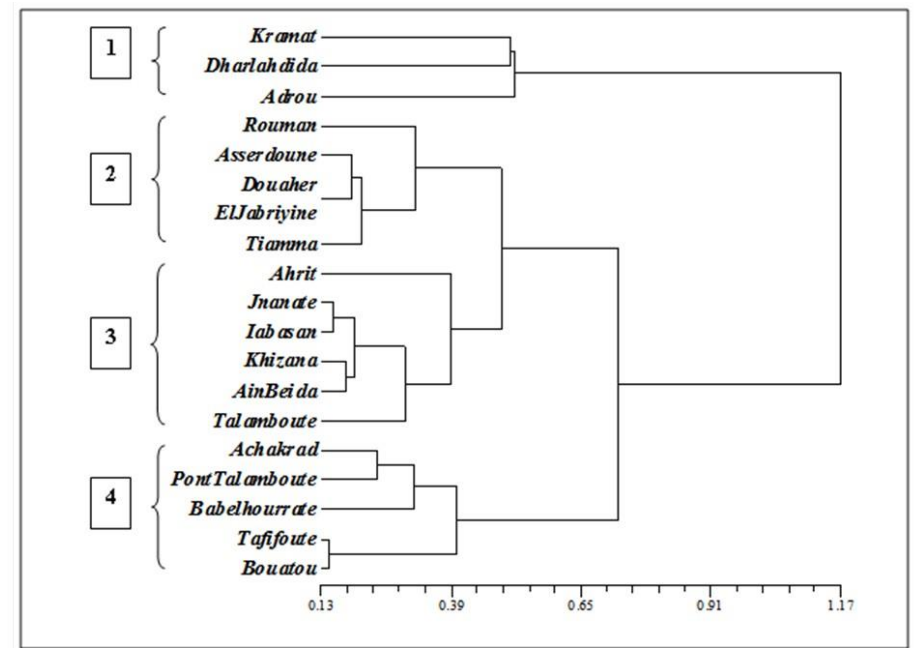

Fig 1. Dendrogram of distance between 19 ecotypes of Vicia ervilia as obtained by the unweighted pair group method with arithmetic means (UPGMA) based on matrix of pairwise Euclidean distance calculated on morphological markers.

(Fig 2). This distance is used to represent the similarity of the genetic structure among populations. The dendrogram clustered four principal groups at a threshold of 0.17 . The three populations Douaher, El Jabriyine and Tiamma are clustered in the same group 3 and are very close to one another in the south of the studied area. The strong similarity among these ecotypes for both morphological and genetic characterization might be explained by the geographic isolation of these sites and their position at the border of vetch culture distribution. We tested for a significant differentiation along a geographical gradient between the north and south of the study area with a Mantel test (Mantel, 1967). This test helps in determining if there is a positive correlation between genetic and geographical distances calculated for the ecotypes studied. The test showed little but significant correlation $(\mathrm{r}=0.171, \mathrm{p}=0.034)$ suggesting that more distant ecotypes are more different genetically. Therefore, a relative isolation by distance, the measured differentiation Fst/(1-Fst) is correlated with the logarithm of the geographical distance between populations (Supplementary Fig 1).

\section{Discussion}

The pods' weight is the most discriminating and variable character. The pods' total length mean is substantially longer than in the accessions studied by Berger et al. (2002), but the average width of the fruit is similar. The average of all populations for the size and shape of the seed of $V$. ervilia are similar to those observed by Altuntas and Karadag (2006) and Hosseinzadeh et al. (2008). The Moroccan ecotypes we measured fall in the average of the species distribution previously described in other studies.

We showed however an important degree of variability for both the size and shape of pods and seeds, resulting in a significant differentiation among the ecotypes we included in our study. The population differentiation along a size gradient was observed but without a clear spatial structure. Indeed, they differ more by the size than by shape.

Significant variations in the size and weight of seeds can open up interesting opportunities for improvement and breeding, and these ecotypes might be included in selection program.. Previous experiments in controlled environments have shown that these variations persist and therefore have a genetic component (El Fatehi et al., 2014) in combination with environmental components. Contrary to morphological data, there is no other study, to our knowledge, that analyzed the genetic diversity in Vicia ervilia with molecular markers. We can thus only compare our results with those from other leguminous species. Therefore, the values of genetic diversity are close to those obtained for other leguminous crops such Vicia faba and Vicia sativa (Suresh et al., 2013; Chung et al., 2013). The various indices estimated showed a high level of polymorphism revealed by SSR markers in Vicia ervilia local 
Table 2. Results of the analysis of variance of the different morphological characteristics of the seed and pod studied in ecotypes of Vicia ervilia. Multiple comparisons of means were performed by Student's Newman and Keuls test (SNK) at the threshold of 5\%.

\begin{tabular}{|c|c|c|c|c|c|c|c|c|c|c|c|c|c|}
\hline \multirow[b]{2}{*}{ Ecotype } & \multicolumn{5}{|c|}{ Seed } & \multicolumn{8}{|c|}{ Pod } \\
\hline & $\begin{array}{l}\mathrm{SH}(\mathrm{mm}) \\
\text { Mean } \pm \\
\text { SD }\end{array}$ & $\begin{array}{l}\text { SD }(\mathrm{mm}) \\
\text { Mean } \pm \\
\text { SD }\end{array}$ & $\begin{array}{c}\text { SY (g) } \\
\text { Mean } \pm \text { SD }\end{array}$ & $\mathrm{HSW}(\mathrm{g})$ & $\begin{array}{l}\text { SH/SD } \\
\text { Mean } \pm \\
\text { SD }\end{array}$ & $\begin{array}{l}\text { PLT }(\mathrm{mm}) \\
\text { Mean } \pm \\
\text { SD }\end{array}$ & $\begin{array}{l}\text { PLB }(\mathrm{mm}) \\
\text { Mean } \pm \\
\text { SD }\end{array}$ & $\begin{array}{c}\mathrm{PW}(\mathrm{mm}) \\
\text { Mean } \pm \mathrm{SD}\end{array}$ & $\begin{array}{c}\text { NSP } \\
\text { Mean } \pm \text { SD }\end{array}$ & $\begin{array}{c}\mathrm{PY}(\mathrm{g}) \\
\text { Mean } \pm \mathrm{SD}\end{array}$ & $\begin{array}{c}\text { PLT/PLB } \\
\text { Mean } \pm \text { SD }\end{array}$ & $\begin{array}{l}\text { PLT-PLB } \\
\text { Mean } \pm \text { SD }\end{array}$ & $\begin{array}{c}\text { PLT/PW } \\
\text { Mean } \pm \text { SD }\end{array}$ \\
\hline Kramat & $4.52 \pm 0.28 \mathrm{a}$ & $4.17 \pm 0.22 \mathrm{a}$ & $0.05 \pm 0.04 \mathrm{a}$ & 3.975 & $1.08 \pm 0.056 \mathrm{a}$ & $25.29 \pm 3.13 \mathrm{a}$ & $21.28 \pm 2 \mathrm{a}$ & $5.32 \pm 2.07 \mathrm{~b}$ & $3.73 \pm 0.45 \mathrm{a}$ & $0.2 \pm 0.03 \mathrm{~b}$ & $1.19 \pm 0.09 \mathrm{a}$ & $4.01 \pm 2.07 \mathrm{a}$ & $4.76 \pm 0.6 \mathrm{a}$ \\
\hline Dharlahdida & $4.54 \pm 0.26 \mathrm{a}$ & $4.18 \pm 0.24 \mathrm{a}$ & $0.05 \pm 0.01 \mathrm{~b}$ & 5.09 & $1.09 \pm 0.05 \mathrm{a}$ & $24.17 \pm 1.88 \mathrm{a}$ & $20.91 \pm 2.04 \mathrm{~b}$ & $5.5 \pm 1.23 \mathrm{a}$ & $3.63 \pm 0.49 \mathrm{~b}$ & $0.21 \pm 0.04 \mathrm{a}$ & $1.16 \pm 0.07 \mathrm{~b}$ & $3.27 \pm 1.23 \mathrm{~b}$ & 4.41 \\
\hline Rouman & $4.46 \pm 0.35 \mathrm{c}$ & $4.11 \pm 0.27 \mathrm{c}$ & $0.05 \pm 0.01 \mathrm{~d}$ & 3.656 & $1.08 \pm 0.06 \mathrm{a}$ & $21.78 \pm 2.09 \mathrm{~b}$ & $18.92 \pm 2.16 \mathrm{c}$ & $4.92 \pm 0.98 c$ & $3.33 \pm 0.48 \mathrm{~b}$ & $0.16 \pm 0.04 \mathrm{c}$ & $1.15 \pm 0.06 \mathrm{c}$ & $2.86 \pm 0.98 \mathrm{c}$ & $4.45 \pm 0.5 b$ \\
\hline Ahrit & $4.12 \pm 0.4 \mathrm{~b}$ & $3.81 \pm 0.31 \mathrm{~b}$ & $0.04 \pm 0.01 \mathrm{c}$ & 4.663 & $1.08 \pm 0.05 \mathrm{a}$ & $22.25 \pm 2.05 c$ & $19.43 \pm 2.23 b$ & $5.31 \pm 0.42 b$ & $3.23 \pm 0.43 \mathrm{c}$ & $0.18 \pm 0.04 d$ & $1.15 \pm 0.06 \mathrm{~d}$ & $2.83 \pm 1.06 \mathrm{~d}$ & $4.2 \pm 0.45 \mathrm{c}$ \\
\hline Adrou & $4.12 \pm 0.33 \mathrm{~b}$ & $3.85 \pm 0.27 \mathrm{~d}$ & $0.04 \pm 0.01 \mathrm{c}$ & 3.732 & $1.07 \pm 0.05 \mathrm{a}$ & $24.16 \pm 1.76 \mathrm{a}$ & $21.37 \pm 1.77 \mathrm{a}$ & $4.82 \pm 0.86 \mathrm{c}$ & $3.67 \pm 0.48 \mathrm{~d}$ & $0.17 \pm 0.04 \mathrm{~d}$ & $1.13 \pm 0.04 \mathrm{e}$ & $2.79 \pm 0.86 \mathrm{e}$ & $5.03 \pm 0.49 \mathrm{~d}$ \\
\hline Achakrad & $3.99 \pm 0.36 \mathrm{~d}$ & $3.75+0.27 \mathrm{e}$ & $0.03 \pm 0.01^{\mathrm{e}}$ & 3.711 & $1.07 \pm 0.05 \mathrm{~b}$ & $20.57 \pm 1.96 \mathrm{~d}$ & $18.1 \pm 2.14 \mathrm{e}$ & $4.89 \pm 0.72 \mathrm{c}$ & $3.37 \pm 0.49 \mathrm{~b}$ & $0.14 \pm 0.03 \mathrm{e}$ & $1.14 \pm 0.05 \mathrm{i}$ & $2.47 \pm 0.72 \mathrm{~g}$ & $4.24 \pm 0.5 \mathrm{e}$ \\
\hline Tafifoute & $3.94 \pm 0.39 \mathrm{~d}$ & $3.59 \pm 0.39 \mathrm{f}$ & $0.04 \pm 0.03 \mathrm{f}$ & 3.606 & $1.1 \pm 0.08 \mathrm{c}$ & $19.88 \pm 2.53 \mathrm{e}$ & $17.36 \pm 2.24 \mathrm{f}$ & $4.87 \pm 1 \mathrm{c}$ & $3.23 \pm 0.5 \mathrm{c}$ & $0.14 \pm 0.03 \mathrm{f}$ & $1.14 \pm 0.06 \mathrm{~d}$ & $2.51 \pm 1 \mathrm{~g}$ & $4.11 \pm 0.59 \mathrm{c}$ \\
\hline Bouatou & $3.8 \pm 0.283 \mathrm{e}$ & $3.59 \pm 0.26 \mathrm{f}$ & $0.04 \pm 0.01 \mathrm{~g}$ & 3.674 & $1.06 \pm 0.05 \mathrm{~d}$ & $20 \pm 2.75 f$ & $17.16 \pm 2.96 \mathrm{~h}$ & $4.73 \pm 1.44 \mathrm{~d}$ & $3.37 \pm 0.61 \mathrm{~b}$ & $0.14 \pm 0.04 \mathrm{e}$ & $1.18 \pm 0.12 \mathrm{~g}$ & $2.84 \pm 1.44 \mathrm{c}$ & $4.25 \pm 0.58 \mathrm{e}$ \\
\hline Jnanate & $4.18 \pm 0.31 \mathrm{f}$ & $3.9 \pm 0.28 \mathrm{~g}$ & $0.04 \pm 0.01 \mathrm{c}$ & 4.178 & $1.07 \pm 0.06 \mathrm{a}$ & $22.2 \pm 2.04 \mathrm{~d}$ & $19.8 \pm 2.28 \mathrm{~g}$ & $4.93 \pm 0.87 \mathrm{c}$ & $3.47 \pm 0.51 \mathrm{~b}$ & $0.18 \pm 0.04 \mathrm{~d}$ & $1.13 \pm 0.06 \mathrm{e}$ & $2.4 \pm 0.87 \mathrm{~g}$ & $4.53 \pm 0.51 \mathrm{f}$ \\
\hline Iabasan & $4.1 \pm 0.31 \mathrm{~b}$ & $387+t-5$ & $0.04 \pm$ & 4.095 & $1.06 \pm 0.05 \mathrm{~d}$ & $22.29 \pm 2.96 \mathrm{c}$ & $20.09 \pm 2.83 i$ & $4.71 \pm 0.47 \mathrm{~d}$ & $3.7 \pm 0.53 \mathrm{~d}$ & $0.16 \pm 0.05 \mathrm{i}$ & & $2.2 \pm 0.47 \mathrm{~g}$ & $4.75 \pm 0.7 \mathrm{a}$ \\
\hline Talamboute & $4.38 \pm 0.28 \mathrm{~g}$ & $4.05 \pm 0.21 \mathrm{i}$ & $0.05 \pm 0.01 \mathrm{~h}$ & 4.494 & $1.08 \pm 0.06 \mathrm{a}$ & $22.72 \pm 1.83 \mathrm{~g}$ & $20.64 \pm 1.84 j$ & $5.08 \pm 0.6 \mathrm{f}$ & $3.53 \pm 0.51 \mathrm{~b}$ & $0.19 \pm 0.02 \mathrm{~h}$ & $1.1 \pm 0.03 \mathrm{~h}$ & $2.07 \pm 0.6 \mathrm{~g}$ & $4.5 \pm 0.49 \mathrm{f}$ \\
\hline $\begin{array}{l}\text { Pont } \\
\text { Talamboute }\end{array}$ & $4.21 \pm 0.32 \mathrm{~h}$ & $3.9 \pm 0.27 \mathrm{~g}$ & $0.04 \pm 0.01 \mathrm{c}$ & 4.191 & $1.08 \pm 0.06 \mathrm{a}$ & $20.3 \pm 2.35 \mathrm{f}$ & $18.3 \pm 2.19 \mathrm{k}$ & $5.1 \pm 0.84 \mathrm{f}$ & $3.27 \pm 0.45 \mathrm{c}$ & $0.16 \pm 0.03 \mathrm{c}$ & $1.11 \pm 0.05 \mathrm{e}$ & $2 \pm 0.84 \mathrm{~g}$ & $4.02 \pm 0.64 \mathrm{~g}$ \\
\hline Khizana & $4.31 \pm 0.24 \mathrm{i}$ & $3.99 \pm 0.24 \mathrm{j}$ & $0.04 \pm 0.01 \mathrm{c}$ & 3.735 & $1.08 \pm 0.06 \mathrm{a}$ & $22.55 \pm 2.01 \mathrm{~g}$ & $20.08 \pm 2.2 \mathrm{i}$ & $4.85 \pm 0.95 \mathrm{c}$ & $3.37 \pm 0.49 \mathrm{~b}$ & $0.16 \pm 0.02 \mathrm{i}$ & $1.13 \pm 0.05 \mathrm{e}$ & $2.46 \pm 0.95 \mathrm{~g}$ & $4.66 \pm 0.49 \mathrm{~h}$ \\
\hline $\begin{array}{l}\text { Bab el } \\
\text { hourrate }\end{array}$ & $3.92 \pm 0.24 \mathrm{~d}$ & $3.59 \pm 0.22 \mathrm{f}$ & $0.03 \pm 0.02^{\mathrm{e}}$ & 3.301 & $1.09 \pm 0.07 \mathrm{~d}$ & $20.26 \pm 2.18 \mathrm{f}$ & $18.51 \pm 21$ & $4.62 \pm 0.52 \mathrm{e}$ & $3.4 \pm 0.5 \mathrm{~b}$ & $0.12 \pm 0.02 \mathrm{~g}$ & $1.09 \pm 0.03 \mathrm{f}$ & $1.75 \pm 0.52 \mathrm{f}$ & $4.41 \pm 0.54 \mathrm{~b}$ \\
\hline Asserdoune & $3.98 \pm 0.22 \mathrm{~d}$ & $3.69 \pm 0.25 \mathrm{k}$ & $50.03 \mathrm{~g}$ & 3.3 & $1.08 \pm 0.06 \mathrm{a}$ & $21.16 \pm 1.98 \mathrm{~h}$ & $19.07 \pm 1.96 \mathrm{c}$ & $5.16=$ & 3.27 & $0.13=$ & 1.11 & 2.05 & 4. \\
\hline Ain $\mathrm{Be}$ & & & & 3.792 & & & & & & & & & \\
\hline Tiamma & 4. & 3. & & 3.79 & $07 \mathrm{~d}$ & $21.43 \pm 1$ & $1.86 \mathrm{~b}$ & 4.9 & 3. & & $05 \mathrm{j}$ & $.78 \mathrm{i}$ & $4.34 \pm 0.4 \mathrm{~b}$ \\
\hline Doual & & 3. & 0 & 3.8 & $1.08 \pm 0.05 \mathrm{a}$ & $20.93 \pm 2.16 \mathrm{~h}$ & $18.99 \pm 2.2 \mathrm{c}$ & $5.08 \pm 0.54 \mathrm{f}$ & $3.27 \pm 0.45 \mathrm{c}$ & $0.15 \pm 0.02 c$ & $1.1 \pm 0.03 \mathrm{j}$ & $1.95 \pm 0.54 \mathrm{j}$ & $4.14 \pm 0.5 c$ \\
\hline El Jabriyine & $4.12 \pm 0.32 \mathrm{~b}$ & $3.85 \pm 0.29 \mathrm{~d}$ & $0.04 \pm 0.01 \mathrm{c}$ & 3.781 & $1.07 \pm 0.05 \mathrm{a}$ & $21.12 \pm 1.72 \mathrm{~h}$ & $18.95 \pm 1.82 \mathrm{c}$ & $4.87 \pm 1.03 \mathrm{c}$ & $3.3 \pm 0.47 \mathrm{~d}$ & $0.16 \pm 0.03 \mathrm{c}$ & $1.11 \pm 0.06 \mathrm{e}$ & $2.18 \pm 1.03 \mathrm{~g}$ & $4.37 \pm 0.53 \mathrm{~b}$ \\
\hline Mean \pm SD & $4.18 \pm 0.30$ & $3.87 \pm 0.27$ & $0.042 \pm 0.02$ & $3.93 \pm 0.44$ & $1.08 \pm 0.06$ & $21.86 \pm 2.18$ & $19.40 \pm 2.16$ & $4.99 \pm 0.88$ & $3.42 \pm 0.49$ & $0.16 \pm 0.03$ & $1.13 \pm 0.05$ & $2.46 \pm 0.92$ & $4.41 \pm 0.51$ \\
\hline $\mathrm{CV} \%$ & 7.13 & 6.9 & 39.47 & 11.2 & 5.29 & 10.03 & 11.21 & 17.66 & 14.31 & 19.66 & 4.72 & 36.51 & 11.57 \\
\hline $\mathrm{F}$ & 41.115 & 37.723 & 4.809 & & 3.058 & 13.625 & 9.282 & 9.972 & 3.267 & 15.518 & 6.357 & 9.323 & 7.6 \\
\hline $\mathrm{P}$ & $<0.0001$ & $<0.0001$ & $<0.0001$ & & $<0.0001$ & $<0.0001$ & $<0.0001$ & $<0.0001$ & $<0.008$ & $<0.0001$ & $<0.0001$ & $<0.0001$ & $<0.0001$ \\
\hline
\end{tabular}

SD: standard deviation, $\mathrm{CV}$ : coefficient of variation, F: variance ratio ( $\mathrm{df}=1.18)$ and P: probability. Code for each character is given in Table 1. For each character, values with the same letter are statistically equal.

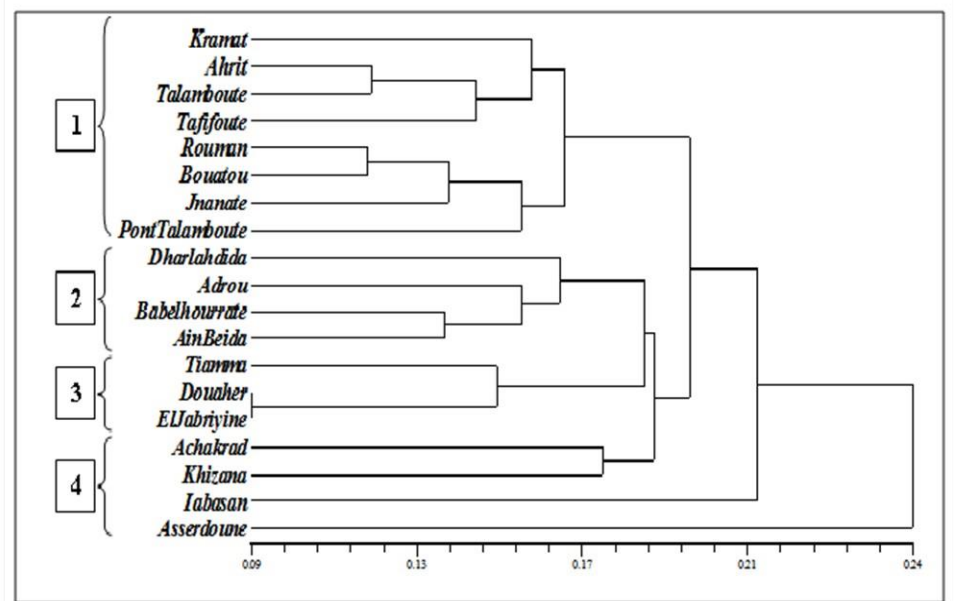

Fig 2. UPGMA tree showing relationships among bitter vetch ecotypes based on Nei's distance calculated on 8 SSR markers. 
Table 3. Genetic diversity of 19 ecotypes of Vicia ervilia at 8 polymorphic loci.

\begin{tabular}{|c|c|c|c|c|c|c|c|c|}
\hline Locus & $A_{P}$ & $\mathrm{~N}_{\mathrm{A}}$ & $\mathrm{N}_{\mathrm{E}}$ & PIC & $\mathrm{M}_{\mathrm{AF}}$ & $\mathrm{N}_{\mathrm{G}}$ & $\mathrm{H}_{0}$ & $\mathrm{H}_{\mathrm{E}}$ \\
\hline VE 02 & 15 & 4 & 2.42 & 0.79 & 0.37 & 16 & 0.043 & 0.587 \\
\hline VE 03 & 8 & 2.63 & 1.83 & 0.62 & 0.55 & 10 & 0.030 & 0.455 \\
\hline VE 05 & 5 & 2.58 & 1.75 & 0.59 & 0.56 & 5 & 0.012 & 0.430 \\
\hline VE 07 & 16 & 4.53 & 2.89 & 0.87 & 0.28 & 21 & 0.044 & 0.654 \\
\hline VE 09 & 6 & 3.58 & 2.44 & 0.80 & 0.25 & 8 & 0.018 & 0.591 \\
\hline VE 14 & 8 & 2.84 & 2.07 & 0.69 & 0.40 & 9 & 0.018 & 0.518 \\
\hline VE 19 & 4 & 2.63 & 1.77 & 0.68 & 0.35 & 7 & 0.029 & 0.436 \\
\hline VE 27 & 3 & 1.42 & 1.17 & 0.24 & 0.86 & 4 & 0.017 & 0.148 \\
\hline Mean & 8.12 & 3.02 & 2.04 & 0.66 & 0.45 & 10 & 0.026 & 0.477 \\
\hline Standard deviation & 4.88 & 0.97 & 0.53 & 0.19 & 0.19 & 5.75 & 0.012 & 0.156 \\
\hline $\mathrm{CV}(\%)$ & 60.09 & 32.15 & 25.99 & 29.47 & 44.04 & 57.57 & 46.25 & 32.71 \\
\hline
\end{tabular}

$\mathrm{A}_{\mathrm{p}}$ : allelic richness, $\mathrm{N}_{\mathrm{A}}$ : average number of alleles per locus, $\mathrm{N}_{\mathrm{E}}$ : effective number of alleles, PIC: polymorphism information content, $\mathrm{M}_{\mathrm{AF}}$ : frequency of the major allele, $\mathrm{N}_{\mathrm{G}}$ : number of genotype, $\mathrm{H}_{0}$ : observed heterozygosity, $\mathrm{H}_{\mathrm{E}}$ : expected heterozygosity and $\mathrm{CV}$ : coefficient of variation

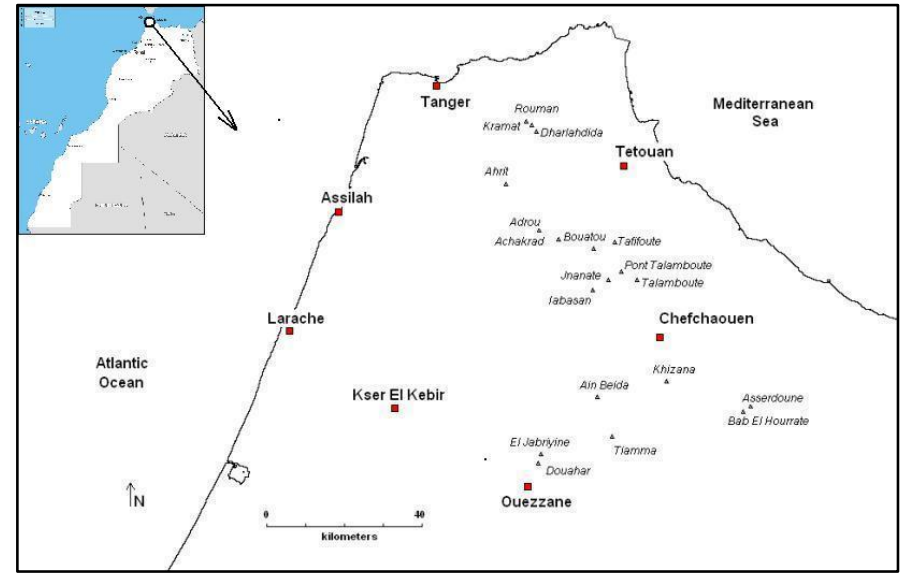

Fig 3. Location map of the surveyed sites.

ecotypes. These values are slightly higher than those observed in other pollinated legumes. Indeed, the number of alleles per locus $\left(\mathrm{A}_{\mathrm{P}}\right)$ observed is higher than in Medicago truncatula $\left(\mathrm{A}_{\mathrm{P}}=3.14\right.$ with 7 loci and 200 accessions, Siol et al., 2008), Lathyrus sativus ( $\mathrm{A}_{\mathrm{P}}=3.88,44$ loci, 24 accessions; Sun et al., 2012) and $V$. sativa $\left(\mathrm{A}_{\mathrm{P}}=5.7,65\right.$ loci, 32 accessions; Chung et al., 2013). However, the average number of alleles per locus (3.026), is higher to that observed in Phaseolus lunatus $\left(\mathrm{N}_{\mathrm{A}}=1.64\right)$ (Ouédraogo et al., 2005). The high contribution of the within-population genetic diversity in the total genetic diversity resulted in a moderate level of genetic differentiation among populations. The value of the $\mathrm{F}_{\mathrm{ST}}(0.194)$ confirmed the moderate level of genetic differentiation among ecotypes, although significant, as suggested by Wright (1931) who considered that the values of $\mathrm{F}_{\mathrm{ST}}$ between 0.15 and 0.25 indicated a significant genetic differentiation. Similar distribution of genetic diversity was observed in other facultative selfing legumes such as Phaseolus lunatus $\left(\mathrm{H}_{\mathrm{T}}=0.220, \mathrm{H}_{\mathrm{S}}=0.153\right.$ and $\left.\mathrm{D}_{\mathrm{ST}}=0.067\right)$ (Ouédraogo et al., 2005). This type of genetic structure was also found in the same study area in Northern Morocco, among ecotypes of Sorghum (Djé et al., 1999), a predominantly selfing species for which however high outcrossing rates in fields have been observed (Barnaud et al., 2008). In these areas, the traditional practices of farmers may explain the persistence of genetic flows between fields. Based on farmer's interviews (El Fatehi et al., 2014), it appears that, if necessary, seeds are obtained from farmers in the neighborhood or in the local market, and thus contribute to a genetic homogenization among populations. A heterozygosity deficit is usually common in self-pollinated crops (Charlesworth and Wright, 2001) and is well-illustrated in leguminous. Indeed $V$. ervilia has been described as a selffertilizing species (Hanelt and Mettin, 1989; Zhang and Mosjidis, 1995). This is also the case for Medicago truncatula $\left(\mathrm{H}_{\mathrm{E}}=0.457\right.$ and $\mathrm{H}_{\mathrm{O}}=0.011$; Siol et al., 2008), Medicago lupulina $\left(\mathrm{H}_{\mathrm{E}}=0.246\right.$ and $\mathrm{H}_{\mathrm{O}}=0.017$; Yan et al., 2009) and Phaseolus lunatus $\left(\mathrm{H}_{\mathrm{E}}=0.143\right.$ and $\mathrm{H}_{\mathrm{O}}=0.012$; Ouédraogo, 2005). The same observation is reported in other self-fertilizing species in the same region and within the same type of agroecosystems Sorghum bicolor (Djé et al., 1999). Conversely it is different in other species with crossfertilizing mating system like $V$. faba $\quad\left(\mathrm{H}_{\mathrm{E}}=0.339\right.$ and $\mathrm{H}_{0}=0.612$; Yang et al., 2012) and Medicago ruthenica $\left(\mathrm{H}_{\mathrm{E}}=0.677\right.$ and $\mathrm{H}_{\mathrm{O}}=0.577$; Yan et al., 2009). Such high genetic diversity, with most of the diversity present within population, is paradoxical regarding the self-fertilizer status of this species. However, such unexpected results have been observed in other selfing species like Medicago truncutula (Siol et al., 2008) and Sorghum bicolor (Djé et al., 1999). This situation could be explained by foundation effects associated with self-fertilization that give birth to subdivided populations into differentiated lineages that escape the effect of drift populations, and maintain diversity (Barton and Whitlock, 1997). Both morphological and molecular approaches have revealed a high level of diversity within ecotypes studied despite the narrowness of the territory and the regression of its culture. The differentiation between ecotypes seems higher from morphological markers. These differences reflect the selective pressures applied by both environmental conditions and selection by cultivation practices of farmers (Djé et al., 1998), relatively to the 
Table 4. Genetic diversity for 19 ecotypes of Vicia ervilia by microsatellites marker.

\begin{tabular}{lllll}
\hline Accession & $\mathrm{H}_{\mathrm{E}}$ & $\mathrm{H}_{0}$ & $\mathrm{P}$ & $\mathrm{N}_{\mathrm{A}}$ \\
\hline Kramat & 0.363 & 0 & 0.87 & 2.37 \\
Dharlahdida & 0.588 & 0.050 & 1 & 3.50 \\
Rouman & 0.510 & 0.028 & 0.87 & 3.12 \\
Ahrit & 0.519 & 0.016 & 1 & 3.12 \\
Adrou & 0.473 & 0.087 & 0.87 & 3 \\
Achakrad & 0.508 & 0.021 & 0.87 & 2.87 \\
Tafifoute & 0.503 & 0.014 & 0.87 & 3.50 \\
Bouatou & 0.628 & 0.083 & 1 & 3.75 \\
Jnanate & 0.511 & 0.028 & 0.87 & 2.75 \\
Iabasan & 0.554 & 0.028 & 1 & 3.25 \\
Talamboute & 0.590 & 0.056 & 1 & 3.62 \\
Pont Talamboute & 0.575 & 0.013 & 1 & 3.87 \\
Khizana & 0 & 0 & 0 & 1 \\
Bab el hourrate & 0.445 & 0 & 0.87 & 2.75 \\
Asserdoune & 0.408 & 0 & 0.87 & 2.50 \\
Ain Beida & 0.546 & 0.014 & 0.87 & 3.25 \\
Tiamma & 0.491 & 0.05 & 0.87 & 3.25 \\
Douaher & 0.422 & 0.016 & 0.75 & 3.12 \\
El Jabriyine & 0.438 & 0 & 0.87 & 2.87 \\
Mean & 0.477 & 0.026 & 0.86 & 3.02 \\
Standard deviation & 0.134 & 0.027 & 0.22 & 0.63 \\
CV (\%) & 28.14 & 101.66 & 25.53 & 20.95 \\
\hline
\end{tabular}

$\mathrm{H}_{\mathrm{E}}$ : expected heterozygosity, $\mathrm{H}_{0}$ : observed heterozygosity, P: percentage of polymorphic loci, $\mathrm{N}_{\mathrm{A}}$ : average number of alleles per locus and $\mathrm{CV}$ : coefficient of variation

Table 5. Estimated Nei's genetic diversity in 19 ecotypes of Vicia ervilia.

\begin{tabular}{lllll}
\hline Locus & $\mathrm{H}_{\mathrm{T}}$ & $\mathrm{H}_{\mathrm{S}}$ & $\mathrm{D}_{\mathrm{ST}}$ & $\mathrm{G}_{\mathrm{ST}}$ \\
\hline VE 02 & 0.798 & 0.662 & 0.136 & 0.170 \\
VE 03 & 0.625 & 0.516 & 0.109 & 0.174 \\
VE 05 & 0.594 & 0.487 & 0.106 & 0.179 \\
VE 07 & 0.871 & 0.739 & 0.132 & 0.152 \\
VE 09 & 0.800 & 0.675 & 0.125 & 0.156 \\
VE 14 & 0.691 & 0.590 & 0.101 & 0.146 \\
VE 19 & 0.678 & 0.493 & 0.185 & 0.273 \\
VE 27 & 0.239 & 0.166 & 0.072 & 0.304 \\
Mean & 0.662 & 0.541 & 0.121 & 0.194 \\
Standard deviation & 0.195 & 0.178 & 0.033 & 0.060 \\
CV $(\%)$ & 29.52 & 32.82 & 27.34 & 30.80
\end{tabular}

$\mathrm{H}_{\mathrm{T}}$ : Total genetic diversity, $\mathrm{H}_{\mathrm{S}}$ : genetic diversity within populations, $\mathrm{D}_{\mathrm{ST}}$ : genetic diversity among populations, $\mathrm{G}_{\mathrm{ST}}$ : coefficient of genetic differentiation and $\mathrm{CV}$ : coefficient of variation.

Table 6. F-statistics for 8 polymorphic loci in Vicia ervilia.

\begin{tabular}{llll}
\hline Locus & $\mathrm{F}_{\mathrm{IT}}$ & $\mathrm{F}_{\mathrm{ST}}$ & $\mathrm{F}_{\mathrm{IS}}$ \\
\hline VE 02 & 0.947 & 0.160 & 0.937 \\
VE 03 & 0.951 & 0.159 & 0.942 \\
VE 05 & 0.980 & 0.173 & 0.976 \\
VE 07 & 0.945 & 0.154 & 0.935 \\
VE 09 & 0.976 & 0.128 & 0.973 \\
VE 14 & 0.973 & 0.146 & 0.968 \\
VE 19 & 0.956 & 0.276 & 0.939 \\
VE 27 & 0.928 & 0.356 & 0.883 \\
Mean & 0.957 & 0.194 & 0.944 \\
Standard deviation & 0.016 & 0.074 & 0.028 \\
CV $(\%)$ & 1.759 & 38.250 & 2.977 \\
\hline
\end{tabular}

$\mathrm{F}_{\mathrm{IT}}$ : fixation of alleles in all populations, $\mathrm{F}_{\mathrm{ST}}$ : genetic differentiation among subpopulations, $\mathrm{F}_{\mathrm{IS}}$ : fixation of alleles within subpopulations and $\mathrm{CV}$ : coefficient of variation. 
supposedly neutral SSR markers. The relative contribution of human selection and environmental pressures in the differentiation among ecotypes remain to be deciphered. Despite a tendency for geographical structuring of genetic differentiation to be low, most of the revealed diversity is within population level. This genetic structure will have a deep impact on the conservation program that should be launched. In the absence of official programs for ex situ conservation, in situ conservation alone is the simplest solution to preserve these genetic resources. Given the nature of the structure of genetic diversity, ecotypes appear as good units for a conservation scheme. Promoting the maintenance of these crops in their traditional agroecosystem is currently the only way to conserved and maintain of the genetic diversity of these local ecotypes. However, at short term, this may not be sufficient because of the threats that endangered this culture; it is thus important to rapidly launch an ex situ conservation plan, including collection and storage of seeds of the various ecotypes.

\section{Materials and Methods}

\section{Plant materials}

A first survey was conducted in the main area of cultivation of bitter vetch in Morocco, in the Tingitan peninsula, in the western Rif (Hmimsa and Ater, 2008). Nineteen sites where bitter vetch was cultivated were chosen and seeds were collected in each of them (Fig 3; Supplementary Table 2). Each accession is composed of 30 individuals sampled directly in bulk from the fields. The pods were sampling from individuals randomly chosen along a diagonal line across the field. Sampling was performing during spring 2009 when pods and seeds were mature, just before harvesting.

\section{Experimental device}

For each accession, 30 pods and 3 seeds per pod were used for the morphological characterization. Thirteen quantitative characters related to size and shape of pod and seed were measured (Table 1). For SSR markers, only 10 individuals per accession were included in the study, resulting in a total of 190 individuals genotyped.

\section{DNA extraction and SSR typing}

Extraction of genomic DNA of $V$. ervilia was made from fresh plant material as described in El Fatehi et al. (2013), adapted from Khanuja et al. (1999). Genotypic typing for each individual was performed according to El Fatehi et al. (2013). Among 24 loci tested (El Fatehi et al., 2013), 9 loci were interpretable and polymorphic. Only eight loci were used in this study (Table 3 ). The lengths of the PCR products are revealed by capillary electrophoresis using an ABI 3730 sequencer, using the size marker Liz500 (Applied Biosystems). The reading of lengths of the fragments is performed using the GeneMapper ${ }^{R}$ software (Applied Biosystems.

\section{Data analyses}

The descriptive statistics, analysis of variance (ANOVA) and multiple comparisons of means (Student's Newman and Keuls test) were performed with the SPSS Statistics Software (17.0). Hierarchical classification (Nei distance for microsatellite data, Euclidean distance for morphological characters and UPGMA clustering method) was performed using the NTSYSpc software (1.05).

The polymorphism was estimated by the average number of alleles per locus $\left(\mathrm{N}_{\mathrm{A}}\right)$, the allelic richness $\left(\mathrm{A}_{\mathrm{P}}\right)$, the percentage of polymorphic loci $(\mathrm{P})$, the major allele frequency $\left(\mathrm{M}_{\mathrm{AF}}\right)$, the number of genotype $\left(\mathrm{N}_{\mathrm{G}}\right)$, the effective number of alleles $\left(\mathrm{N}_{\mathrm{E}}\right)$ and the PIC (Polymorphism Information Content). The effective number of alleles $\left(\mathrm{N}_{\mathrm{E}}\right)$ was calculated with the formula $\mathrm{N}_{\mathrm{E}}=1 /\left(1-\mathrm{H}_{\mathrm{E}}\right)$, (Berg and Hamrick, 1997). The PIC value was calculated according to the formula: $\mathrm{PIC}=1-\sum_{\mathrm{j}=1}^{\mathrm{n}} \mathrm{Pij}^{2}$, where $\mathrm{Pij}$ is the frequency of the jth allele at the ith locus (Anderson et al., 1993).

Estimation of the various parameters of genetic diversity is performed using GENETIX (4.03) and FSTAT (2.9.3.2) software. We estimated the observed heterozygosity $\left(\mathrm{H}_{0}\right)$, the expected heterozygosity $\left(\mathrm{H}_{\mathrm{E}}\right)$, the total genetic diversity $\left(\mathrm{H}_{\mathrm{T}}\right)$, the genetic diversity within populations $\left(\mathrm{H}_{\mathrm{S}}\right)$, the genetic diversity among populations $\left(\mathrm{D}_{\mathrm{ST}}=\mathrm{H}_{\mathrm{T}}-\mathrm{H}_{\mathrm{S}}\right)$ and the coefficient of gene differentiation $\left(\mathrm{G}_{\mathrm{ST}}=\mathrm{D}_{\mathrm{ST}} / \mathrm{H}_{\mathrm{S}}\right)(\mathrm{Nei}$, 1987). Wright's fixation indices $\left(\mathrm{F}_{\mathrm{IS}}, \mathrm{F}_{\mathrm{ST}}\right.$ and $\mathrm{F}_{\mathrm{IT}}$ ) (Weir and Cockerhamm, 1984), partitions the genetic diversity within a species by estimating: the fixation of alleles in all populations $\left(\mathrm{F}_{\mathrm{IT}}\right)$ and in subpopulations $\left(\mathrm{F}_{\mathrm{IS}}\right)$, and genetic differentiation among subpopulations $\left(\mathrm{F}_{\mathrm{ST}}\right)$.

The isolation by distance among populations was tested through the Mantel procedure implemented in GenAlex (Peakall and Smouse, 2012), with 1000 random permutations. Genetic differentiation between each pair of populations was tested using Genepop 4.0 (Rousset, 2008), with 1000 iterations and 1000 iterations per batch.

\section{Conclusion}

Both morphological and molecular approaches have revealed a high level of diversity within ecotypes studied despite the narrowness of the territory and the regression of culture. The differentiation between ecotypes is higher from morphological markers relative to molecular markers. This result can be explained by the nature of morphological markers which are more exposed to the environment and subjected to selection by cultivation practices of farmers.

These ecotypes are maintained in traditional agroecosystems which play the role of neglected resource conservatory. So the conservation of these genetic resources depends on the conservation of traditional agroecosystem and local knowledge.

\section{Acknowledgments}

This work was supported by OREAL-UNESCO award "For Women and Science" 2009 and a scholarship program UNESCO/MAB for Young Scientists 2010. We also thank Dr. Younes Hmimsa, Dr. Aicha El Oualkadi and Mr. Badr Khouzima for their help and Dr. Finn Kjellberg for valuable comments on an earlier version of the manuscript.

\section{References}

Abd El-Moneim AM, Saxena MC (1997) Developing cultivated forage legumes for improved yield and quality to feed livestock in the dry areas. In: Haddad N, Tutwiler R, Thomson E (eds): Improvement of crop-livestock integration systems in west Asia and north Africa. Proceedings of the regional symposium on integrated croplivestock systems in the dry areas of West Asia and North Africa, 6-8 November 1995, Amman, Jordan. ICARDA, Aleppo, Syria. 
Altuntas E, Karadag Y (2006) Some physical and mechanical properties of sain foin (Onobrychis sativa Lam.), grass pea (Lathyrus sativus L.) and bitter vetch (Vicia ervilia (L.) Willd.) seeds. Journal of Applied Sciences (6): 1373-1379.

Anderson JA, Churchill GA, Autrique JE, Tanksley SD, Sorrells ME (1993) Optimization parental selection for genetic linkage maps. Genome 36 (1): 181-186.

Ater M, Hmimsa Y (2008) Agriculture traditionnelle et agrodiversité dans le bassin versant d'Oued Laou (Maroc). In: Bayed A, Ater M (eds) : Du bassin versant vers la mer : Analyse multidisciplinaire pour une gestion durable. Travaux de l'Institut Scientifique, Rabat, série générale (5): 107-115.

Barnaud A, Trigueras G, McKey D, Joly H (2008) High outcrossing rates in fields with mixed sorghum landraces: how are landraces maintained? Heredity (101): 445-452.

Barton NH, Whitlock MC (1997) The evolution of metapopulations. In: Hanski I, Gilpin ME (eds): Metapopulation biology: ecology, genetics and evolution. Academic Press, San Diego: 183-210.

Berg EE, Hamrick JL (1997) Quantification of genetic diversity at allozyme loci. Canadian Journal of Forest Research (27): 415-424.

Berger JD, Robertson LD, Cocks PS (2002) Agricultural potential of Mediterranean grain and forage legumes: key differences between and within Vicia species in terms of phenology, yield, and agronomy give insight into plant adaptation to semi-arid environments. Genetic Resources and Crop evolution (49): 313-325.

Bounejmate M (1997) Le patrimoine fourrager et pastoral au Maroc: acquis et perspectives. In : Birouk A, Rejdali M (eds): Ressources phytogénétiques et développement durable. Actes éditions, Rabat, Maroc, 219-238.

Charlesworth D, Wright S (2001) Breeding systems and genome evolution. Current opinion in genetics \& development 11 (6): 685-690.

Chung JW, Kim TS, Suresh S, Lee SY, Cho GT (2013) Development of 65 novel polymorphic DNA-SSR markers in common vetch (Vicia sativa subsp. sativa) using next generation sequencing. Molecules (18): 8376-8392.

Djé Y, Ater M, Lefébvre C, Vekemans X (1998) Patterns of morphological and allozyme variation in sorghum landraces of northwestern Morocco. Genetic Resources and Crop Evolution (45): 541-548.

Djè Y, Forcioli D, Ater M, Lefébvre C, Vekemans X (1999) Assessing population genetic structure of sorghum landraces from north-western Morocco using allozyme and microsatellite markers. Theor Appl Genet. (99): 157-163.

Djé Y, Heuertz M, Lefébvre C, Vekemans X (2000) Assessment of genetic diversity within and among germplasm accessions in cultivated sorghum using microsatellite markers. Theor Appl Genet. (100): 918-925.

Djé Y, Heuertz M, Ater M, Lefébvre C, Vekemans X (2007) Evaluation de la diversité morphologique des variétés traditionnelles du sorgho dans le Nord-ouest du Maroc. Biotechnol Agron Soc Environ. (11) 1: 39-46

El Fatehi S, Béna G, Filali-Maltouf A, Ater M (2014) Variation in yield component, phenology and morphological traits among Moroccan bitter vetch landraces. African Journal of Agricultural Research (9): 1801-1809.

El Fatehi S, Béna G, Sbabou L, Filali-Maltouf A, Ater M (2013) Preliminary results for user SSR markers in bitter vetch "Vicia ervilia (L.) Willd". International Journal of Research. In: Agriculture and Food Science (1): 40-46.

Enneking D (1995) Post-harvest detoxification: the key to alternative Vicia grain legumes. In: Yusuf HKM, Lambein
F (eds): Lathyrus sativus and Human Lathyrism: Progress and Prospects. University of Dhaka: 85-92.

FAO (2015) http://faostat3.fao.org/download/Q/QC/E.

Foury A (1954) Les légumineuses fourragères au Maroc (deuxième partie). Les cahiers de la recherche agronomique, INRA, Rabat, (5): 287-658.

Francis CM, Enneking D, Abd El-Moneim AM (1999) When and where will vetches have an impact as grain legumes? In: Knight $\mathrm{R}$ (ed): Linking research and marketing opportunities for pulses in the 21 st century. Proceedings of the third international food legume research conference, Adelaide 1997. Current Plant Science and Biotechnology in Agriculture. Kluwer Academic Publishers, Dordrecht/Boston/London. (34): 671-683.

Frankel O, Brown AHD, Burdonn JJ (1995) The conservation of plant biodiversity. New York, USA: Cambridge University Press, 299 p.

Germplasm Resources Information Network (GRIN) (2008) GRIN taxonomy for Plants. United States Department of Agriculture, Agricultural Research Service, Beltsville Area.

Hanelt P, Mettin D (1989) Biosystematics of the genus Vicia L. (Leguminosae). Annu Rev Ecol Syst. (20): 199-223.

Hmimsa Y, Ater M (2008) Agrodiversity in the traditional agrosystems of the Rif mountains (North of Morocco). Biodiversity: Journal of life on earth (9): 78-81.

Hosseinzadeh Z, Pakravan M, Tavassoli A (2008) Micromorphology of seed in some Vicia species from Iran. Rostaniha (9): 96-107.

Khanuja SPS, Shasany AK, Darokar MP, Kumar S (1999) Rapid isolation of DNA from dry and fresh samples of plants producing large amounts of secondary metabolites and essential oils. Plant Molecular Biology Reporter (17):17.

Lazaro A, Villar B, Aceituno-Mata L, Tardio J, De la Rosa L (2013) The sierra norte of Madrid: an agrobiodiversity refuge for common bean landraces. Genetic Resources and Crop Evolution (60):1641-1654.

Lev E, Kislev M, Bar-Yosef O (2005) Mousterian vegetal food in Kebara Cave. Mt Carmel J Archaeo Sci 32(3): 475484.

Mantel N (1967) The detection of disease clustering and a generalized regression approach. Cancer Res. 27(2): 209220.

Maxted N (1995) An ecogeographical study of Vicia subgenus Vicia. Systematic and ecogeographic studies on crop genepools 8. International Plant Genetic Resources Institute. Rome, Italy.

Nei M (1987) Molecular evolutionary genetics. Columbia University Press, New York. USA.

Ouédraogo M, Maquet A, Baudoin J P (2005) Étude comparative de la diversité et de la structure génétique de populations sauvages de Phaseolus lunatus L. à l'aide des marqueurs enzymatiques et microsatellites. Biotechnologie, Agronomie, Société et Environnement (BASE) 9 (3): 195205.

Peña-Chocarro L, Zapata L (2010) Neolithic agriculture in southwestern Mediterranean region. In: Gibaja JF, Faustino CA (Eds) Os últimos caçadores-recolectores e as primeiras comunidades produtoras do sul da Península Ibéricae do norte de Marrocos. Promontoria monográfica (15): 191198.

Peakall R, Smouse PE (2012) GenAlex 6.5: genetic analysis in excel. Population genetic software for teaching and research - an update. Bioinformatics (28): 2537-2539.

Rousset F (2008) Genepop version (4.0): a complete reimplementation of the genepop software for Windows and Linux. Molecular Ecology Resources (8): 103-106. 
Siol M, Prosperi JM, Bonnin I, Ronfort J (2008) How multilocus genotypic pattern helps to understand the history of selfing populations: a case study in Medicago truncatula. Heredity (100) : 517-525.

Sun XL, Yang T, Guan JP, Ma Y, Jiang JY, Cao R, Burlyaeva M, Vishnyakova M, Semenova E, Bulyntsev S, Zong XX (2012) Development of 161 novel EST-SSR markers from Lathyrus sativus (Fabaceae). American Journal of Botany 99(10): 379-390.

Suresh S, Park JH, Cho GT, Lee HS, Baek HJ, Lee SY, Chung JW (2013) Development and Molecular Characterization of 55 novel polymorphic cDNA-SSR markers in faba bean (Vicia faba L.) using 454 pyrosequencing. Molecules 18(2):1844-1856.

Trnka M, Olesen JE, Ker Sebaum KC, Skjelvag AO, Eitzinger J, Seguin B, Peltonen-Sainio P, Rotter R, Iglesias A, Orlandini S, Dubrovsky M, Hlavinka P, Balek J, Eckersten H, Clloppet E, Calanca P, Gobin A, Vuecetic V, Nejedlik P, Kumar S, Lalic B, Mestre A, Rossi F, Kozyra J, Alexandro V, Semeradova D, Zalud Z (2011) Agroclimatic conditions in Europe under climate change. Global Change Biology, doi: 10.1111/j.1365-2486.2011.02396.x

Weir BS, Cockerham CC (1984) Estimating F-statistics for the analysis of population structure; Evolution 38(6): 13581370.

Wright S (1969) Evolution and the genetics of populations, Vol. II. The Theory of Gene Frequencies. University of Chicago Press, Chicago.
Yan J, Chu HJ, Wang HC, Li JQ, Sang T (2009) Population genetic structure of two Medicago species shaped by distinct life form, mating system and seed dispersal. Annals of Botany 103(6): 825-834.

Yang T, Bao SY, Ford R, Jia TJ, Guan JP, He YH, Sun XL, Jiang JY, Hao JJ, Zhang X Y, Zong XX (2012) Highthroughput novel microsatellite marker of faba bean via next generation sequencing. BMC Genomics, (13): 602 .

Zhang X, Mosjidis JA (1995) Breeding systems of several Vicia species. Crop science Society of America 35(4): 1200-1202.

Zohary D, Hopf M, Weiss E (2012) Domestication of plants in the Old World. New York, Oxford University Press. $3^{\mathrm{e}}$ ed., $264 \mathrm{p}$. 